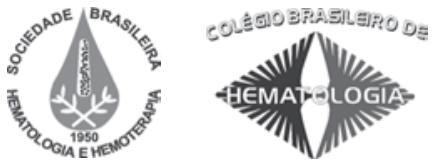

\title{
Células infectadas pelo eritrovírus B19
}

\section{Cells infected by erythrovirus B19}

\author{
Sheila O.Garcia ${ }^{1}$, Ester C. Sabino², Gracia M. Martinez ${ }^{3}$
}

O eritrovírus, anteriormente descrito como parvovírus B19, é um membro da família Parvoviridae. Devido ao alto tropismo para células eritropoéticas, o B19 foi incluído no gênero Erytrovirus, pois se replica apenas em células eritróides da medula óssea e do sangue. ${ }^{1}$ Como consequência da infecção viral há inibição da eritropoese e efeitos citotóxicos. A infecção inicia-se quando o capsídeo liga-se ao antígeno P. O antígeno Pé um glicoesfingolipídeo da linhagem vermelha, especialmente expresso nos proeritroblastos. ${ }^{2}$

A infecção pelo eritrovírus pode apresentar manifestações clínicas como o eritema infeccioso, a artropatia, a crise aplásica transitória, a aplasia pura de células vermelhas, a erupção papular, purpúrica em mãos e pés e hidropisia fetal. Algumas manifestações são relacionadas à maior morbimortalidade e são a encefalopatia, epilepsia, meningite, miocardite, cardiomiopatia dilatada e hepatite autoimune. O eritrovírus tem sido sugerido por vários autores como agente causal em várias síndromes clínicas, o que por vezes é de difícil comprovação. ${ }^{3}$ A presença de precursores eritróides gigantes, com inclusões citoplasmáticas e granulação eosinofílica é altamente sugestiva de infecção pelo eritrovírus, porém o teste mais preciso para a confirmação do diagnóstico é a pesquisa de DNA viral pelo método de PCR (Reação em Cadeia da Polimerase).

\section{Referências Bibliográficas}

1. Valera ET, Cipolotti R, Bernardes JE, Pacagnella RC, Lima DM, Tone LG, et al. Pancitopenia transitória induzida por parvovírus B19 em criança portadora de esferocitose hereditária. J. Pediatr. 2000; 76(4):323-6.

2. Brown KE, Anderson SM, Young NS. Erythrocyte P antigen: cellular receptor for B19 parvovirus. Science. 1993;262:114-7.

3. Setúbal S, Oliveira SA, Angelis FD, Serôdio AC, Nascimento JP. Manifestações clínicas associadas ao parvovírus B19, incluindo a anemia persistente na AIDS e em outras formas de imunodepressão. J Bras Doenças Sex Transm. 2001;13(4):55-60.

Suporte Financeiro: Fapesp

Avaliação: Editor e dois revisores externos

Conflito de interesse: não declarado

Recebido: 14/11/2008

Aceito: 25/11/2008

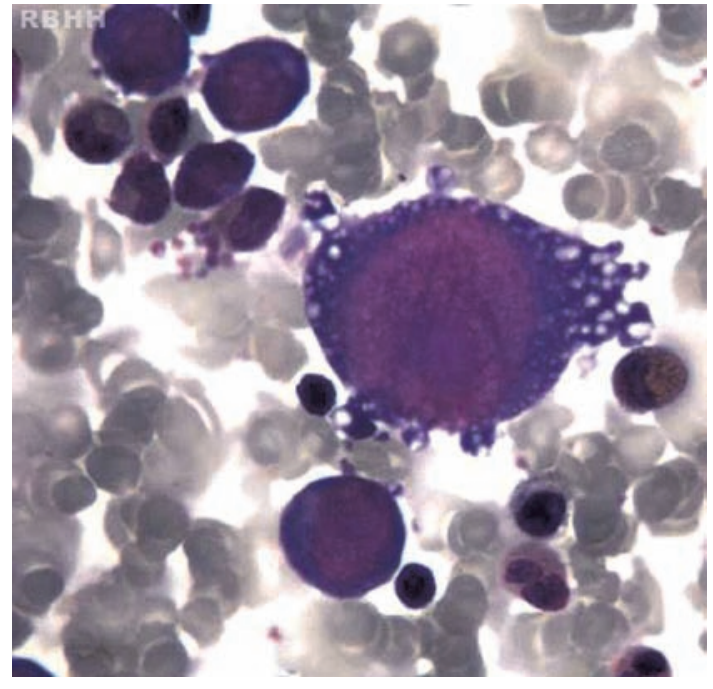

Figura 1. Proeritroblasto gigante com inclusões citoplasmáticas sugerindo infecção pelo eritrovírus B19. Medula óssea, coloração por Leishman, aumento X 1000.

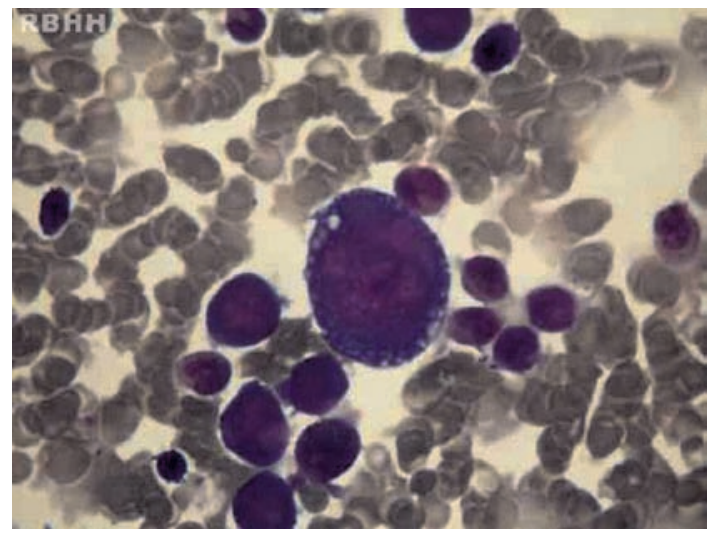

Figura 2. Eritroblasto com vacuolização citoplasmática sugerindo infecção pelo eritrovírus B19. Medula óssea, coloração por Leishman, aumento X 1000.

${ }^{1}$ Aluna do curso de Mestrado em Processos Imunes e Infecciosos da Faculdade de Medicina da USP - São Paulo-SP.

${ }^{2}$ Médica chefe do Departamento de Biologia Molecular da Fundação Pró-Sangue.

${ }^{3}$ Médica assistente do Serviço de Hematologia do Hospital das Clínicas da Faculdade de Medicina da USP - São Paulo-SP.

Correspondência: Sheila de Oliveira Garcia

Av. Dr. Enéas Carvalho de Aguiar, 155 - $1^{\circ}$ andar, bloco 4, sala 61, Laboratório de Imunopatologia

05403-000 - Cerqueira César - São Paulo-SP - Brasil

Email: sheilagarcia.hp@gmail.com 